\title{
The Assessment of Parents' Awareness of Children Immunization as per Universal immunization program (UIP)
}

\author{
Research Article
}

\section{Harsha Dipak Vaidya1, Premkumar P Badwaik2*}

\author{
1. UG Student, 2. Associate Professor \& HOD, Department of Swasthavritta
}

Mahatma Gandhi Ayurved College, Hospital \& Research Centre, Salod (H), Wardha.

\begin{abstract}
There are numerous diseases which cause infection in the human beings, it may get cured with medication or without the medication and some of them are become fatal. There are some diseases which get cured completely but leaves behind some damage in human, like polio. This damage not cause physically but also cause mental trauma to children. So, it is better to prevent the disease before manifestation, for that immunization is the best way to prevent and protect from disease by giving medication like a vaccine. Large populations of parents are not aware of the benefits of the immunization. Awareness regarding the vaccination among a small town population is less. The aim by this Survey is parents' awareness of children immunization as per Universal immunization program (UIP). For survey, conducted the cross-sectional observational questionnaire-based community survey in the Yelikeli village of Wardha district, where the assessment of the children immunizations should do up to the age of 5 years. In $94 \%$ population of parents are known about the vaccination, which has to be given to their children of age between 1-4 years. Around $82 \%$ of parents get information regarding immunization by Anganwadi sevika. The survey concludes that the government immunization coverage reached to the small village. Most effective mode to provide information about the vaccination program was door to door advertisement which reduces the chances of missing doses of vaccination and because of that parent is well aware of the UIP schedule. The vaccine is enough sufficient to avert severe disease.
\end{abstract}

Key Words: Additional Vaccination, Child Health, Disease Prevention, Routine Vaccination.

\section{Introduction}

Immunization is a simple and effective way of protecting yourself and your family by getting to immune and bring resistance against infectious diseases, by the progressive administration of a vaccine. According to the World health organization, the vaccine helps to protect the large population against the disease and the infection by stimulating the body's own immune system.(1) (2)

According to WHO in 2017, 116.2 million highest reported numbers of children to get immunized in the world. In India, successfully achieving the coverage in basic immunization is $65 \%$. $86 \%$ of the world's children receive vaccinations that protect them against polio, diphtheria, tetanus, pertussis, measles, and etc. vaccine-preventable disease.

But despite that according to the survey in 2018, due to vaccine-preventable disease, about 1.5 million children die each year. And in India, there are 5

\section{* Corresponding Author:}

\section{Premkumar P Badwaik}

Associate Professor \& HOD,

Department of Swasthavritta,

Mahatma Gandhi Ayurved College, Hospital \& Research Centre, Salod (H), DMIMS (Deemed to be University), Wardha, Maharashtra, India.

Email Id: badwaik.prem@gmail.com lakh children die due to vaccine-preventable disease. Although India is the leading producer and exporter of vaccine still is the home of the one-third of the world's non-immunized children said Health affairs. (3)

The survey identifies the implementation of government policies at the root level like small towns and villages with the illiterate population of the country. Also hints the rate of the extension activities run by the government in this population. This survey also tries to explore about awareness of the parents regarding the immunization program. This survey is found beneficial for the stakeholders to know about the flaws of the immunization program.

It is a survey study, whose main aim is Review of parents' awareness of children Immunization as per Universal immunization program (UIP) at small town Yelikeli, Wardha District, Maharashtra. However, to assess the immunization status of children, parents' awareness about children immunisation and awareness regarding the UIP are the main objective of this study.

\section{Method}

The cross-sectional observational questionnaire based community survey in the Yelikeli village of Wardha district was conducted. The data was collected through re-validated questionnaire then it was further analyzed and interpreted. Cross-section case study design was adopted for the study. It was an empirical enquiry aimed at strengthening routine immunization in 
the country. There are 11 questionnaires were prepared for each 50 study sample size. The information regarding the parents' knowledge about vaccination, regarding the schedule of immunizations program which was planned by the government this all had assessed by the questionnaire.

\section{Observation and Results}

There were total 50 samples taken in study, from one family only one child is taken up to the age of 5 years that to elder child. To recognize the immunization programme reach to the yelikeli village which governed by the government and the assessment of the parents regarding awareness of immunization as well as to check whether the children may or may not be suffering from the vaccine preventable disease in Yelikeli Village. For that statistical data are mentioned below which was analyzed from questionnaires' given to the villagers.

Table 1: Age-wise distribution of children

\begin{tabular}{|c|c|c|} 
Age of the child & $\begin{array}{c}\text { No of } \\
\text { children }\end{array}$ & Percentage \\
\hline $0-1$ yr & 10 & 20 \\
\hline $1-2$ yrs & 15 & 30 \\
\hline $2-3$ yrs & 12 & 24 \\
\hline $3-4$ yrs & 6 & 12 \\
\hline $4-5$ yrs & 7 & 14 \\
\hline Total & 50 & 100 \\
\hline
\end{tabular}

In the survey, the children from age group 0-1 years were $20 \%$. Percentage of the children between the age group 1-2 years were $30 \%$. Children between the ages of $2-3$ years were $24 \%$. $12 \%$ of the children are between 3-4 years age group. Children between the ages of $4-5$ yrs were $14 \%$. (Table 1 )

Table 2: Showing Parents knowledge regarding Vaccination in percentage.

\begin{tabular}{|c|c|c|c|c|c|c|}
\hline $\begin{array}{c}\text { Vacci } \\
\text { natio } \\
\text { n } \\
\text { Detail } \\
\text { s }\end{array}$ & $\begin{array}{c}\text { Know } \\
\text { about } \\
\text { vacci } \\
\text { natio } \\
\text { n }\end{array}$ & $\begin{array}{c}\text { Impo } \\
\text { rtanc } \\
\text { e of } \\
\text { vacci } \\
\text { natio } \\
\text { n }\end{array}$ & $\begin{array}{c}\text { Recei } \\
\text { ve } \\
\text { neces } \\
\text { sary } \\
\text { vacci } \\
\text { natio } \\
\text { n }\end{array}$ & $\begin{array}{c}\text { Vacci } \\
\text { natio } \\
\mathbf{n} \\
\text { irreve } \\
\text { rsible }\end{array}$ & $\begin{array}{c}\text { Side } \\
\text { effect } \\
\text { s of } \\
\text { vacci } \\
\text { natio } \\
\text { n }\end{array}$ & $\begin{array}{c}\text { Alle } \\
\text { rgy } \\
\text { saw } \\
\text { in } \\
\text { chil } \\
\text { dre } \\
\text { n }\end{array}$ \\
\hline Yes & $94 \%$ & $74 \%$ & $92 \%$ & $82 \%$ & $24 \%$ & $54 \%$ \\
\hline No & $2^{\circ}$ & & $4 \%$ & $8 \%$ & $4 \%$ & $46 \%$ \\
\hline $\begin{array}{l}\text { Not } \\
\text { Sure }\end{array}$ & \% & 0 & $4 \%$ & $10 \%$ & $\%$ & 0 \\
\hline Total & $100 \%$ & $100 \%$ & $100 \%$ & $100 \%$ & $100 \%$ & 100 \\
\hline
\end{tabular}

The above table shows that $94 \%$ of the parents are having the knowledge of parents regarding vaccination like $94 \% .92 \%$ of parents were believed that receiving vaccination was necessary for their children. $82 \%$ of parents were believed that the effect of not receiving the vaccination is irreversible. $74 \%$ of parents were known about the importance of the vaccination. $74 \%$ of parents were not worried about the possible side effect of vaccination. In $54 \%$ of children after vaccination allergy was seen, allergies like a fever.
While the remaining $46 \%$ of children are not allergic to the vaccination (Table 2).

Table 3: Sources, for parents, to get information regarding the immunization

\begin{tabular}{|l|c|c|}
$\begin{array}{l}\text { Source of } \\
\text { information }\end{array}$ & No of parents & Percentage \\
\hline By Doctor & 17 & 34 \\
\hline By TV & 0 & 0 \\
\hline By Anganwadi & 31 & 62 \\
\hline By Nurse & 2 & 4 \\
\hline By Relatives & 0 & 0 \\
\hline General Awareness & 0 & 0 \\
\hline
\end{tabular}

It comes to know that there are many different sources of immunization to parents, like $62 \%$ of the parents were get the information of immunization from the Anganwadi ASHA. It supposed to be the best source of information among the parents. However, $34 \%$ of the parents were get the information from the Doctor. Remaining $4 \%$ of information was got by the nurse of PHC. (Shown in Table 3).

\begin{tabular}{|c|c|c|}
\hline Knowledge & $\begin{array}{l}\text { No of } \\
\text { parents }\end{array}$ & Percentage \\
\hline $\begin{array}{l}\text { Advertisements about } \\
\text { upcoming vaccination on } \\
\text { TV }\end{array}$ & 8 & $16 \%$ \\
\hline $\begin{array}{l}\text { Door to door } \\
\text { advertisement by nurses }\end{array}$ & 32 & $64 \%$ \\
\hline $\begin{array}{l}\text { Small awareness program } \\
\text { carried out in Anganwadi }\end{array}$ & 10 & $20 \%$ \\
\hline None of the above & 0 & 0 \\
\hline
\end{tabular}

The best way of spreading the knowledge regarding immunization schedule among the parents was the door to door advertisement by nurses said by $64 \%$ of the parents. $20 \%$ got the information regarding immunization by the small awareness program carried out in Anganwadi. 16\% of the parents were got information about the immunization by Advertisements. (Table 4)

Below data shows the doses of vaccination to prevent the child from the immunization disorder up to the age of 5 years since the childbirth.

Table 5: After birth how many doses of vaccinations are given to your child up to the age of 5 years

\begin{tabular}{|l|c|c|}
\hline Doses of vaccination & $\begin{array}{l}\text { No of } \\
\text { children }\end{array}$ & Percentage \\
\hline 0 to 1 & 1 & $2 \%$ \\
\hline 2 to 3 & 16 & $32 \%$ \\
\hline 4 to 5 & 22 & $44 \%$ \\
\hline 5 to 6 & 9 & $18 \%$ \\
\hline 6 to 8 & 2 & $4 \%$ \\
\hline Total & 50 & $100 \%$ \\
\hline
\end{tabular}

Parents did not know about how many doses of vaccination should be given to their children after birth up to the age of 5 years until the awareness program 
was held by the government. Only $4 \%$ of the children have received the 6 to 8 doses of the vaccination at the age of the 5 yrs. $18 \%$ of the children received the 5 to 6 dose of vaccination only. 4 to 5 doses of vaccination got by $44 \%$ of the children. $32 \%$ of children got $2-3$ doses of the vaccination. Still, $2 \%$ of the children received the $0-1$ doses of vaccination at the age of 5 yrs after such immunization schedule program. (Table 5)

Table 6: Knowledge about optional vaccination

\begin{tabular}{|l|c|c|} 
Optional Vaccination & $\begin{array}{c}\text { No of } \\
\text { children }\end{array}$ & Percentage
\end{tabular}

\begin{tabular}{|l|c|c|}
\hline $\begin{array}{l}\text { Pneumococcal conjugate, } \\
\text { flu vaccine }\end{array}$ & 1 & 2 \\
\hline Rubella & 11 & 22 \\
\hline Mumps & 1 & 2.4 \\
\hline Rabies & 1 & 2.7 \\
\hline Versella & 2 & 5.5 \\
\hline PCV & 2 & 5.8 \\
\hline Influenza & 1 & 3 \\
\hline
\end{tabular}

Other than regular children immunization program only $45.8 \%$ of the parents know about the optional vaccination. Mostly known is Rubella vaccination i.e. $22 \%$. (Table 6 )

\section{Discussion}

This is the survey type study conducted at a village among the sample of 50 parents. The crosssectional observational questionnaire-based community survey in the village was developed for this study and the analysis method was used. However, a similar approach has been taken for other studies assessing knowledge scores. (4) As per the survey conducted at Yelikeli village regarding parent's responsiveness about the childhood immunization. Most of the parents knew about vaccination, they took their children time to time, up to the age of 5 years to protect them from the diseases, which can occur at any stage of life. $94 \%$ of parents know that, the vaccination has to be given to their children of age between $1-4$ years. Around $82 \%$ of parents got information regarding immunization by Anganwadi sevika. To make parents aware about the immunization, most preferable method of advertisement is the door to door publicity. It helps every single parent to make them know about vaccination and its side effects if any.

Due to the decrease of public confidence in vaccine safety, it may lower the vaccination rate as well as, revitalize vaccine-preventable diseases. According to Some parents, vaccines are unsafe and ineffective. The diseases caused by vaccines are mild and uncommon. Because of that they are not ready for vaccinate their children, that leads to the risk of their own child's life. (5) During the survey, it was revealed that the parents had good knowledge regarding Universal immunization program but limited awareness of the knowledge towards newer vaccines as well as optional vaccination. (6)

The main reason of Immunization delayed was due to lack of family support, poor participation of the male as well as negative attitude of the elderly at home, gender bias, common childhood illness, apprehension of giving many vaccines at one time and adverse rumours. Some other reasons which come as barriers in it included economic impaction, nearby unavailability of the health facility, and inconvenient timings and lack of effective communication with doctors. (7)

Now in the era of digitization, it is considered that internet is the best way to reach up to the parents (8) but still in a small village, door to door advertisement is considered as the best way to reach up to them.

Children under 1 year of age are mostly unlike to receive the OPV/DPT 3rd dose as well as measles vaccine. The most influencing factors of immunization coverage are Mother's education. Sex of a child had no significance. (9)

There is low Coverage of optional vaccines, because of the high cost and lack of awareness (10). Optional vaccination should be included in the routine vaccination schedule accordingly to the endemic diseases.

\section{Conclusion}

This survey concludes that the government immunization coverage reached to the small village. As $94 \%$ of the parents of Yelikeli village were aware of the purpose and benefits of vaccination. About $99 \%$ of the Yelikeli village children were fully immunized to date. Parents were vaccinating their children time to time up to the age of 5 years. Most effective mode to provide information of vaccination program was door to door advertisement which reduces the chances of missing doses of vaccination and because of that parent is well aware of the UIP schedule. The vaccine is enough sufficient to avert severe disease. For every socioeconomic class, vaccination is the better line of treatment for the preventable disease as it cost less. Immunization may be considered as the keystone of the children health.

\section{References}

1. https://www.who.com/ health topic/ immunization/ 2018\# dated 05-05-2020 time 13.30 IST

2. Ghai, Essential Pediatrics.Immunization and Immunodeficiency. 8 ed. CBS Publications; reprint 2014.188- $189 \mathrm{p}$.

3. McQuestion $M$ et al, Creating Sustainable Financing and Support for Immunization Programs in Fifteen Developing Countries. Health Affairs, 2011, vol.30 (6); 1134-1140

4. Herath N.C, Kudagammana T, Sanathchandra T.T, Gamage H.K, Razik I.M, Liynapathirana V, BMC Res Notes. 2018 Jun 22; 11(1):402.

5. Kurane A. B, Swathi D. A study of the immunization status of children in the age group 25 years. Into J Contempt Pediatric. 2018; 5: 922-7

6. Knowledge and Awareness of parents about universal immunization program and optional vaccines: a cross-sectional study in Central India, 
Indian Journal of Basic and Applied Medical Research; March 2018, Vol.-7, Issue- 2, P. 585-593.

7. Vinayak A. Improving immunization coverage in rural India: clustered randomized controlled evaluation of immunization campaigns with and without incentives. BMJ. 2010; 340p

8. Jones A. M et al, Parents' Source of Vaccine Information and Impact on Vaccine Attitudes, Beliefs, and Nonmedical Exemptions, Advances in
Preventive Medicine, Hindawi Publishing Corporation, Volume 2012, Article ID 93274; 1-8 p

9. Chaudhary V, Tiwari M, Ghoghare M. Immunization Status of 1-5-Year-Old Children and Factors Affecting It: A Hospital-Based Study. Pediatric On calls J. 2015; 12: 67-68.

10. Predictors of optional immunization uptake in an urban south Indian population, Vaccine Volume 32, Issue 27, 5 June 2014, Pages 3417-3423, Science Direct. 